\title{
Angry Bird Game Application for Improving Manipulative Motion Learning Outcomes for Students of Class II Public Elementary School 060863 Medan T.A. 2018/2019
}

\author{
Atikah Rahman \\ Department Of Sport Education \\ Post Graduate Program, State University Of Medan \\ Medan, North Sumatera, Indonesia. \\ Rahmanatikah81@gmail.com
}

\begin{abstract}
Abstrak- Research and development of this angry bird game to improve manipulative basic motion learning outcomes for elementary school students in grade II, specifically there are several objectives, including: 1) To obtain in-depth information about the process of implementing manipulative basic motion learning for elementary students. 2) Develop and implement angry bird game in improving the results of learning manipulative motion for elementary students. 3) Obtain empirical data about the effectiveness, efficiency and attractiveness of the results of the development of the angry bird game to improve the results of learning basic manipulative motion for elementary students. The time of this study was planned for one month, namely in October 2018. The target of the clients or users who were the target in the research on the development of traditional games to improve the results of manipulative basic motion learning in grade II elementary school children with a small group test of 12 people and a large group test of 24 people. In the research of traditional game development to improve the results of manipulative basic motion learning in grade II elementary school children is a process used to develop and validate learning products. Research and development in this learning uses the Research \& Development development model
\end{abstract}

Keywords : Angry Bird Game, Traditional Game, Games.

\section{INTRODUCTION}

Indeed learning is a human characteristic so that humans can be distinguished from animals. According to Hamalik in Hamdani (2011: 17) learning is done by humans throughout his life, anytime, and anywhere, both in school, class, street and in a time that is not predetermined. Even so learning is done by humans always by specific intentions and intentions.

According to Sudjana (2010: 22) learning outcomes are abilities that students have after receiving learning experiences. The results of learning activities are characterized by a relatively permanent positive behavior change in the person who is learning. In connection with that opinion, then someone can be said to have succeeded in learning if he is able to show a change in him. These changes include the ability to think, skills, or attitude towards an object.

In teaching, we always know the goals we must achieve in teaching a subject. For that we formulate specific instructional objectives based on Bloom's taxonomy of behavioral goals. Appearances observed as learning outcomes are called abilities. According to Gagne there are 5 abilities that are viewed in terms of what is expected from a teaching or instruction. That ability needs to be distinguished because that ability allows various kinds of human appearance and also because the conditions for obtaining various abilities are different.

Understanding the motion given by an elementary school teacher is very decisive for these students to be able to move actively in activities in various sports, both individual sports and team sports, as well as individuals. Children at primary school age in accordance with the objectives of the applicable physical education curriculum, are expected to obtain motor knowledge and understanding that are considered important for the success of adapting to adult life. In general, games performed by elementary school students are the development of basic movements taught by physical education teachers. Basic motion is a need that must be learned in elementary school age, considering that it will be needed to support the development of posture in adolescence and adulthood. Basic motion includes locomotor, non-locomotor and manipulative. These three basic movements are in the curriculum of elementary school children in low grades I, II and III.

Manipulative motion involves the act of controlling an object, especially with the hands and feet. There are two classifications of skills from manipulative motion, namely receptive and propulsive. Receptive skill is accepting an object such as capturing and propulsive skills have a sense of force or force against an object, such as hitting, throwing, bouncing or kicking. 
Many things affect the stages of learning motion, according to Rahantoknam (1998: 240) The stages that are passed in the process of learning the motion are: (1) cognitive stage, (2) fixation stage for closed motion and associative stage for open motion, (3) autonomization stage. Manipulative skills are developed when children are mastering various objects. Manipulative skills involve more hands and feet, but other parts of the body's organs can also be used. Object manipulation is far superior to eye-foot and hand-eye coordination, which is quite important for items; walk (move steps) in space. Usually the teacher sees that manipulative motion is a combination of locomotor and non-locomotor movements.

Although most manipulative skills use hands and feet, other parts of the body can also be used. Manipulation of certain objects leads to better eye-hand and eye-foot coordination, especially important for movements that follow the path or trajectory (tracking) in certain places.

Manipulative skills are the basics of various game skills (game skills). Movement that requires energy, such as throwing, hitting, and kicking and movement of receiving objects, such as capturing are important skills that can be taught using various types of balls. The movement of bouncing or directing a floating object, such as volleyball is another very important form of manipulative skill. Control of an object that is carried out continuously, such as using a stick or hoop is also manipulative activity.

Based on this thought, it is carried out by observing students who include running, jumping, jumping, throwing, and spinning. These movements are movements that are often carried out by elementary school students. Based on observations at SD Negeri 060863 Medan in class II students that there were problems:

Where from all the examples of manipulative movements chosen by the researcher, it turns out that only a few students understand the instructions. And students are not interested if the material is carried out just to do the movement without the game.

Based on the observations of teachers and researchers that elementary school children have a game virus on a smartphone, observations made several months by the teacher where students talk during breaks usually discuss games on smartphones and this is a negative influence of technology that has attacked children's thinking. Where should children play at their age but instead use smartphones without parental guidance. Smartphone addiction is a very complex problem if it occurs in early childhood.

Researchers also found motor problems in some children that there were children who were trembling when instructed to run, there were children who were easily tired when instructed to jump and there were children who were unable to perform a series of running, jumping, throwing and spinning movements.

Based on the observations of researchers that physical education teachers do not apply the concept of playing an interesting game so to provide learning manipulative basic motion will be very difficult to provide stimulus to students and the learning objectives will not be maximized.

The Education Curriculum covers six aspects of development namely moral and religious values,socialemotional and independence,language, cognitive, physical / motoric, and artistic abilities.is a form of early childhood education program. Elementary school is an education level that must be followed and provide benefits for preparing children to enter junior high school. In general, learning in elementary schools for many aspects of physical development has been done by adjusting to certain sports. Physical exercise in early childhood should still pay attention to simple basic movements. Simple movements will make children easy to understand and carry out instructions. This will also minimize the occurrence of injuries to children.

If the physical development of the child gets an exercise that is in accordance with the characteristics of the child, then the tendency of the child will be easier to achieve in the desired sport. Children's motor skills begin with basic motion exercises. Basic motion is very important in an effort to instill the correct foundation in motion. Therefore, it is necessary to have a discussion about what basic movements are important and must be controlled by the child.

Traditional games are games that are often played by children at school age. Children who play traditional games always feel strong, and with pleasure they will do it earnestly and solely get pleasure from the play. Sukintaka (1992: 91) limits the meaning of traditional games is a game that has been played by children in an area traditionally. The tradition here is that the game has been inherited from the next generation of next generation. So, the game has been played by children from one age to the next.

Playing for children is an exciting thing. Especially traditional games which involve many children and are in open spaces. So, it is not wrong with the results of Kurniati's research (Novi, 2016: 75). In his research he showed that traditional games can stimulate children in developing cooperation to help children adjust, interact positively, can condition children in self-control, develop empathy for friends, obey rules, and respect others. Thus, it can be understood that traditional games can have a very good impact to help develop children's emotional and social skills.

The angry bird game in this study was adopted from catapult games in traditional games. As for the nature of the catapult according to Novi (2016: 146) this game uses a tool made of wood which is shaped like a letter Y or derived from branched wood, measuring $25 \mathrm{~cm}$ high. On both ends of the wood, black or red drawstring rubber with a length of $55 \mathrm{~cm}$ is installed. Along with the development of the era of traditional games lost swallowed by the development of online games and games that are on smartphones. With the problems in the background above the author concludes that the development of learning is needed, which can provide motivation to learn and be useful, interesting and effective in learning basic manipulative movements and provide convenience to physical education teachers in delivering material. So the researchers raised the title of the research "Angry Bird Game Application to Improve Learning Outcomes of Manipulative Motion in 
Students of Class II SD Negeri 060863 Medan T.A. $2018 / 2019$

\section{METHOD}

In the research of traditional game development to improve the results of manipulative basic motion learning in grade II elementary school children is a process used to develop and validate learning products. Research and development in this learning uses the Research \& Development (R \& D) development model from Borg \& Gall (1983: 776) which consists of ten steps, including: 1) Conducting research and gathering information (literature review, subject observation, report preparation subject matter) (2) Planning (defining skills, formulating goals, determining teaching sequences, and small-scale trials) (3) Developing initial product forms (preparation of teaching materials, preparation of handbooks and evaluation tools) (4) Conducting tests starting field (using 6-12 subjects) (5) Revising the main product (in accordance with suggestions from the results of the initial field test) (6) Conducting the main field test (with 30100 subjects. (7) Revising the product ( based on suggestions and results of the main field trials) (8) Field testing with 40200 subjects (9) Revision of the final product (10) Making a report on the product in the journal, working with publish that can conduct commercial distribution

\section{RESULT AND DISCUSSION}

This angry bird game is to improve the results of manipulative basic motion learning for elementary school children in grade II, in particular there are several objectives including:

1. To obtain in-depth information about the process of implementing manipulative basic motion learning for elementary students.

2. Develop and implement angry bird game in improving the results of learning manipulative motion for elementary students.

3. Obtain empirical data about the effectiveness, efficiency and attractiveness of the results of developing an angry bird game to improve the results of learning basic manipulative motion for elementary students.

The ultimate goal of this development research is to produce a product in the form of a game module that contains traditional games to improve the learning outcomes of manipulative basic motion with text-based media for elementary school students in grade II, so that it can complement the existing learning, namely that students can learn more :

1. Effective, meaning that it is complete in increasing the effectiveness or convenience for students in mastering manipulative basic motion material. Efficiency, the meaning is the completeness of learning assistance, where with minimal costs and time so that maximum results can be obtained in mastering manipulative basic motion material.

2. Interesting, meaning that it is the completeness of learning that has appeal so that students can be motivated to use it.

The target of the client or user who is the target in the research on the development of traditional games to improve the results of learning manipulative basic motion in elementary school children in grade II with a total of 30 students.

In this development, the trial subjects used included a review of experts consisting of 4 experts, namely 2 physical education learning experts and 2 traditional game experts. Qualifications of experts in this development must be determined in the role of evaluating or revising. For experts in physical education learning (1) an expert who works or is competent in the field of physical education learning, (2) has a minimum work period of 3 years. Whereas for traditional game experts must have characteristics, among others: (1) lecturers at Unimed Faculty of Mathematics and Natural Sciences, (2) mastering physical education learning (3) holding learning courses related to games.

The subject of needs analysis was 30 students of Public Elementary School 060863 Medan.

- Phase I trials, the trial subjects were 12 students of SDN 105289 Pond taken using purposive sample technique.

- Phase II trials, the trial subjects consisted of 24 SDN 105289 Ponds

\section{REFERENCES}

[1] Borg. W. R \& Gall, M. D. 1983. Educational Research An Introduction New York : Longman.

[2] B,E, Rahantoknam. 1998. Belajar Motorik Teori dan Aplikasinya Dalam Pendidikan Jasmani dan Olahraga. Jakarta: Dikti, P2LPTK.

[3] Hamdani (2011). Strategi Belajar Mengajar. Bandung: Pustaka Setia

[4] Nana Sudjana. 2010. Penilaian Hasil Proses Belajar Mengajar. Bandung: PT Remaja Rosdakarya

[5] Novi Mulyani. 2016. Super Asyik Permainan Tradisional Anak Indonesia. Yogyakarta: DIVA Pres. 